\title{
The Role Of Beekeeping On Forest Conservation And Poverty Alleviation In Moshi Rural District,Tanzania
}

\author{
Gileard S. Minja, MSc. \\ Theresia J. Nkumilwa, BA \\ Department of Geography; Mwenge Catholic University (MWECAU), \\ Moshi, Tanzania
}

doi: 10.19044/esj.2016.v12n23p366 URL:http://dx.doi.org/10.19044/esj.2016.v12n23p366

\begin{abstract}
The study examined The Role of Beekeeping in Forest Conservation and Poverty Alleviation in Moshi Rural District. It was guided by the following research objectives firstly to examine the challenges of beekeeping, secondly to identify the market, products and technology used in beekeeping and lastly to examine the contributions of beekeeping on forest conservation and poverty alleviation in Moshi rural district. The study employed mixed research design where by 70 beekeepers were sampled. Both primary and secondary data were employed in this study. Different methods were used in data collection which included house hold questionaire, interviews, wealth ranking, observation and focus group discussion. Statistical package for social science (SPSS) version 16 and microsoft excel were used to analyze quantitative data. Findings revealed that $40 \%$ of sampled beekeepers agreed that beekeeping contributed to forest and biodiversity conservation through afforestation programs. which imply Results revealed that there is strong positive relationship $(r=0.718)$ between numbers of beehives and liters of honey produced in a year in Moshi rural district. Majority, 75\% of the sampled beekeepers disagreed to the fact that beekeeping contributes to poverty alleviatio. This is because majority lacks skills, reliable market and appropriate technology. The findings further revealed that financial constraint is the most emerging challenge where by $62 \%$ of the respondents said they lack finaces to buy modern beehives.
\end{abstract}

Keywords: Beekeeping, Forest Conservation and Poverty alleviation 


\section{Introduction}

Globally beekeeping provides sustainable livelihoods to many smallscale farmers and other rural and non-rural people (Bradbear, 2003). Beekeeping deals with the management of bees and processing of bee products from natural forests, plantations, agricultural land and other habitats. Beekeeping products include honey, beeswax, royal jelly, propolis and pollination services (URT, 1998). It is a source of employment, provides income to the people, a source of recreation, ecotourism and foreign exchange earnings (MNRT, 2001). Beekeeping also plays major role in improving biodiversity and increasing crop production through pollination (Mwakatobe, 2001). Bees also offer a large potential with minimal investments (Hilmi, 2012). Tanzania is endowed with favorable environment for production of honey, beeswax and other bee products. The country has about 48.1 million hectares of forests and woodlands, which are scattered throughout and are ideal for developing beekeeping industry (Mkamba, 2013). In Moshi rural beekeeping is practiced in several villages including among others Mtakuja at Mabogini Ward, Kibosho, Uru, Kilema, Marangu basically for ncome and environment conservation (Keyyu, 2003).

\section{Statement of the research problem}

The development of beekeeping activities for income generation and forest management is hindered by forest degradation, poor technology and marketing system for bees products. The continuing forest loss is a telling measure of the imbalance between human needs, wants and nature capacity (Salim \& Ullsten, 1999). Mwakatobe (2001), explains about beekeeping as a major practice in improving biodiversity and increasing crop production through pollination. Furthermore a report by (Mmasa, 2007), explains economic analysis of honey production and marketing where he analyses the economic factors that affect honey production and market in Hai district. Beeswax is among the important products of beekeeping, which is often neglected as a source of income or as a resource to be utilized within the household (Krell, 1996).

Findings from various studies for example Lalika ( 2005), Mwakatobe ( 2001), Mmasa (2007), Krell (1996), evidences that beekeeping has been supporting the livelihood, economy and health of many communities also enhances ecosystem service through pollination. However its full potential has not yet being explored in forest conservation and poverty alleviation. Hence this study will examine the role of beekeeping on forest conservation and poverty alleviation in Moshi rural district, Kilimanjaro. 


\section{Objectives of the study}

The general objective of the study aimed at examining the role of beekeeping on forest conservation and poverty alleviation in Moshi rural district. The study was guided by the following specific objectives:-

1. To examine the challenges of beekeeping at Moshi rural district

2. To identify the market, products and technology used in beekeeping at Moshi rural district.

3. To examine the contributions of beekeeping on forest conservation and poverty alleviation in Moshi rural district

\section{Literature review}

\section{Categories of beekeeping and their management}

\section{i. Modern beekeeping}

Modern beekeeping can satisfy social economic demands and at the same time restores and conserves the ecosystem's integrity (USDA, 2012). Modern beekeeping is a win-win intervention in buffer zones and degraded ecosystems that satisfies both social economic and ecological demands. It is used to improve household incomes and conservation of ecosystems or restoration of degraded ones by conservation agencies in the region (USDA, 2012).

\section{ii. Traditional beekeeping}

Beekeeping especially in East Africa is mostly carried out using traditional methods. In this methods, beehives are made out of logs, bark, reeds, gourds and pots among other materials (Musimba, 2004). The activity is quite adaptable to various environments and conditions however farmers are unable to access better markets due to the poor quality and low quantity of honey produced. It may lead to bush fire due to use of fire during honey harvesting (Musimba, 2004).United States Department of Agriculture reported that bee colony losses averaged $17 \%-20 \%$ per year between the 1990s and mid 2000s is caused by various factors such as mites, diseases, and management stress. Managed bees are commercially important, wild bee species are important ecologically for sustainable forests and fields (USDA, 2012).

\section{The products of beekeeping}

Honey is the main product produced out of beekeeping activity. It is a natural sweetener that is widely used in the food, beverage, bakery and pharmaceutical industries. Other beekeeping by products is bee wax, it has a lot of industrial uses particularly in the manufacturing of cosmetics, candles, polishes and pharmaceuticals, Propolis is used in the manufacturing of antibiotics. Bee keepers often use this product to seal unwanted gaps in the beehives and attracting bees to new beehives, Bee Venom has potential for 
use as treatment for various ailments and for treating bee allergies, Royal Jelly has potential use in the cosmetic industry, Bee Brood is the developmental stages of bees, which is a rich source of proteins (Bradbear, 2009).

\section{Marketing and sale of beekeeping products}

The internal markets for honey and beeswax are not well established however demands for honey and beeswax exceed supply in the international market. The local marketing structure involves individual farmers, cooperatives, Community Based Organizations, Non Governmental Organizations, traders, processors, packers and other actors in the value chain. The main challenges facing marketing of hive products include; poor marketing infrastructure, inadequate marketing information, poor market organization, unethical marketing practices and high consumer prices due to low supply (Gupta, 2014). Beekeeping is a potential source of additional income; it is seen as an important occupation and part of rural life worldwide where access to income is limited (UNDP, 2002).

\section{Beekeeping versus forest conservation and poverty alleviation}

Bees are important pollinators and many ecosystems depend on the pollination by bees for their existence and for increasing their genetic diversity through cross-pollination. Bee pollinators strongly influence ecological relationships, ecosystem conservation and stability, genetic variation in the plant community, floral diversity, specialization and evolution. Bees play an important role in ecosystem services (Crane, 1999). Generally honey bees are important pollinators responsible for healthy development of the environment through enhancing transfer of pollen grains which necessitate genetic diversity of different species. Also honey bees facilitate self employment and income generation to individual by sell of honey products, the generated income from beekeeping activities may be used to pay social services like education, electricity, health, transport and build better housing this facilitates poverty alleviation (URT, 1998).

\section{Research methodology}

The study was conducted in Mweka and Kibosho Umbwe villages found in Moshi rural district. Sample of the study consisted of 70 beekeepers using household questionnaire it was guided by mixed research design because of its flexibility to collect data from diverse situations. Both primary data and secondary data were employed in the study. Primary data were collected using questionnaires for beekeepers, interview for beekeepers, beekeeping officer and village leaders, wealth ranking for beekeepers, observation and focus group discussion which involved two groups namely 
Holela community group and Roots and Shoots group found in Mweka village. Secondary data was collected through document analysis where published, unpublished materials and research reports were reviewed and major findings analyzed. Statistical package for social science (SPSS) version 16 and Microsoft excel were used in qualitative data .Relationship between the number of beehives and the produced liters of honey per year in Moshi rural district was analyzed using correration coefficient. The data are presented in different ways which includes tables, figures and plates.

\section{Results and discussion}

\section{Social demographic information of the respondents}

The social demographic information of the respondents in the study area included sex, age, education level, marital status, economic activities and size of the household. Majority of beekeepers in the study area were male with $78.6 \%$ as compared to $21.4 \%$ who were female. This portrays that beekeeping is an activity which is dominated by male due to the fact that female fear nature of stinging by bees and lack of confidence in climbing trees to set up beehives in flowering plants. Also customs and traditions is one of the factors which portray domination of males in beekeeping activities Data from the field reveals that, $64.3 \%$ were farmers, $14.3 \%$ of respondents practiced agriculture while $4.3 \%$ of respondents practiced business and environmental conservation, $2.9 \%$ of respondents practiced livestock keeping and beekeeping.

\section{Challenges of beekeeping at Moshi rural district}

Data from the field reveals that $62.9 \%$ of the respondents were facing financial challenges while $18.6 \%$ of respondents experienced ecological challenges, $15.7 \%$ of the respondents encountered technical challenges and finally $2.9 \%$ of the respondents experienced absconding of bees in hives before harvesting time.

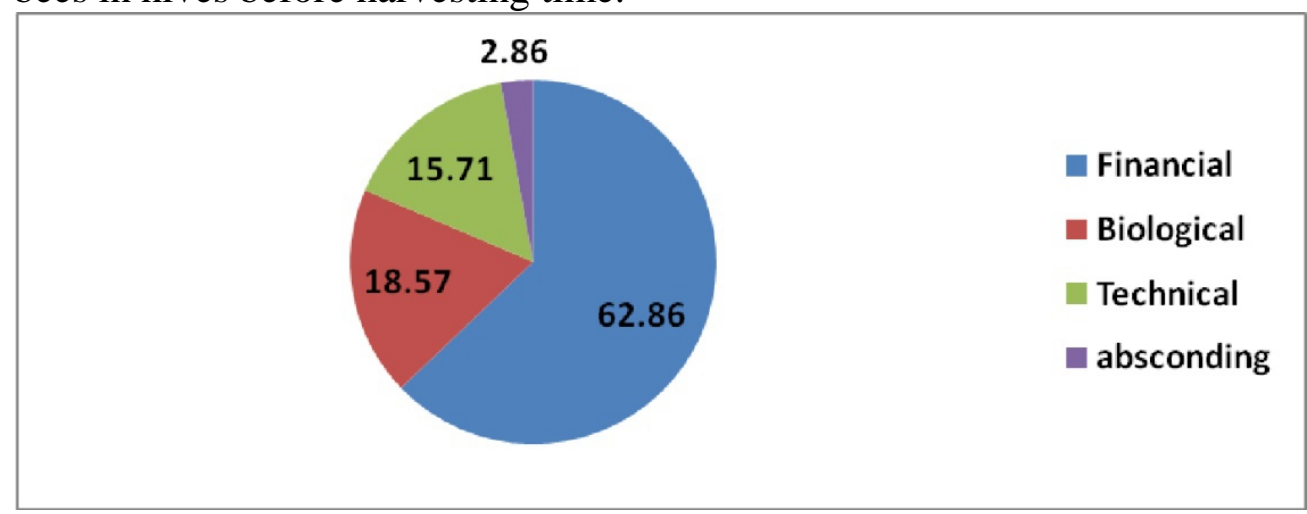

Figure 1: Challenges facing beekeeping farmers on honey production Source: field data March, 2016. 


\section{The current challenges of beekeeping in Moshi rural district}

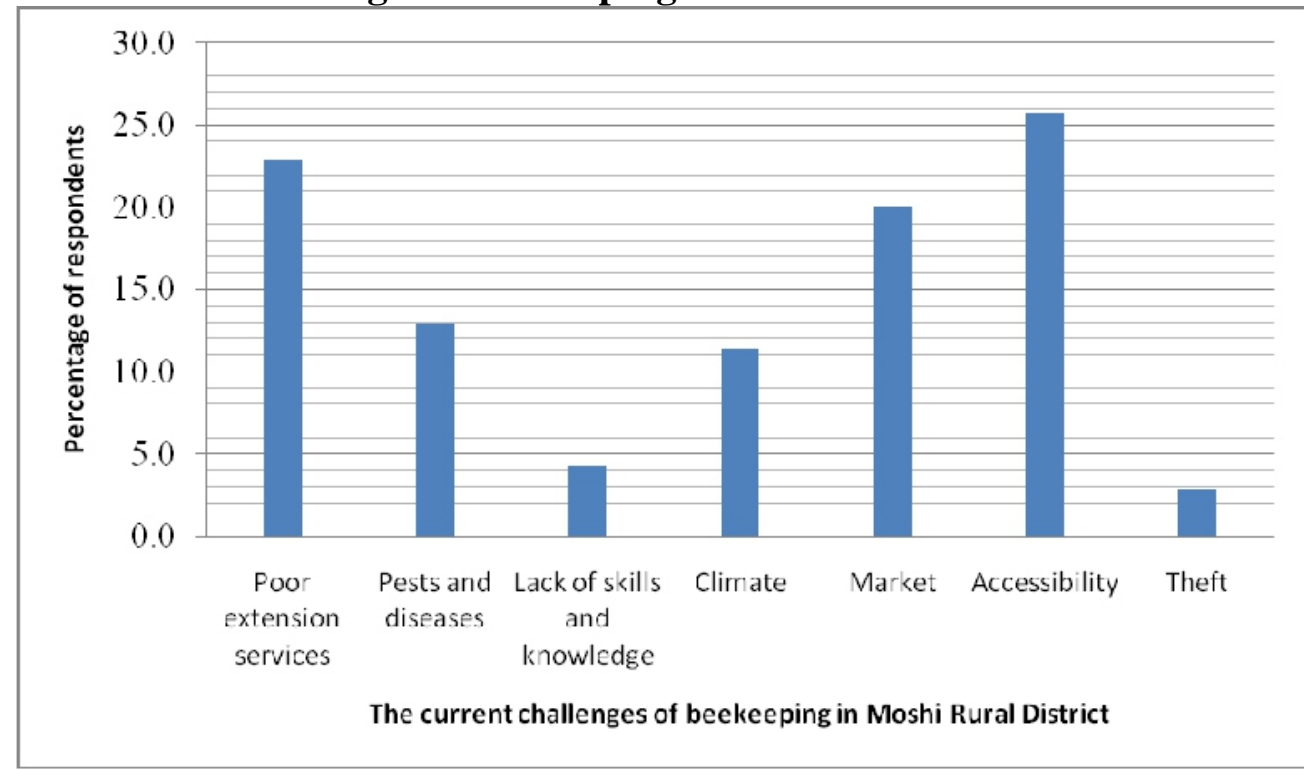

Figure 2: The current challenges of beekeeping in Moshi rural district Source: field data March, 2016.

Findings from figure 2 above reveals that $25.7 \%$ of the respondents lacks accessibility to areas for practicing beekeeping which require enough space, $22.9 \%$ of respondents were challenged with poor extension services, $20 \%$ of respondents were lacking market, $12.9 \%$ of respondents said spreading of pest and diseases, $4.3 \%$ of respondents were lacking skill and knowledge, $11.4 \%$ of respondents were affected by climate impacts and finally $2.9 \%$ of respondents said theft is among current challenge of beekeeping in Moshi rural district.

Market, Products and Technology used in Beekeeping at Moshi Rural District

Generally beekeeping market operate locally with mainly honey as main produced product while other products like bees wax are neglected and wasted with the exceptional of few beekeepers. The technology used in beekeeping consists of both modern and traditional technologies whereby traditional one is dominant.

\section{Beekeeping products produced in the area}

Findings from table 1 below, reveals that $97.1 \%$ of sampled beekeepers produced honey while $2.9 \%$ produced bees wax, this group comprised of those using wax for producing of cosmetics such as sneering oils also candles. During observation and interviews majority beekeepers produced honey for income generation and domestic use such as food and 
medicine. Also interview with key informants at Umbwe villlage (beekeepers, beekeeping officer and village leaders) portrayed that, majority beekeepers produced honey only and wasted bees wax with the exceptional of the few. The findings concur with (Bradbear, 2009) who find that honey is the main product produced in beekeeping activity.

Table 1: Beekeeping products produced in the area $(n=70)$

\begin{tabular}{cc}
\hline Beekeeping products & Percent (\%) \\
\hline Honey & 97.1 \\
Bees wax & 2.9 \\
\hline Total & 100.0 \\
\hline
\end{tabular}

Source: field data March, 2016.

\section{Market for honey and wax}

Data from table 2 below reveals that $51.4 \%$ of sampled beekeepers sell their products in the local market while $44.3 \%$ of the respondents do not access market for their products neither in the local nor national market, 2.9 $\%$ of the respondents sells their products in local and international market.

Table 2: Market of honey and wax $(n=70)$

\begin{tabular}{cc}
\hline Market of honey and wax & Percent (\%) \\
\hline Local market & 51.4 \\
International market & 1.4 \\
None & 44.3 \\
Both local and international market & 2.9 \\
\hline Total & 100 \\
\hline
\end{tabular}

Source: field data March, 2016.

This is due to the fact that they produce honey and use it domestically for food and medicine also local brew made with honey. Furthermore local market is dominant compared to other markets this explains people loose interest over beekeeping as it does not raise their income from honey and wax selling.

\section{Technology used in beekeeping}

Findings from figure 2 below show that $82.9 \%$ of the sampled beekeepers used traditional beekeeping technology. $14.3 \%$ of the respondents used modern beekeeping technology while $2.9 \%$ of the respondents used both modern and traditional beekeeping technologies. Majority (82.9\%) of the sampled beekeepers used tradition beekeeping due to customs and traditions inherited from ancestors also avoiding the expensive modern beehives which are sold at eighty thousands Tanzania shillings (8,000tsh) and one hundred and twenty thousand Tanzanian shillings(120,000tsh) respectively . During interview with one of the beekeeper revealed that,"majority of beekeepers use smoker leading to fire 
outbreaks in forests also vegetation covers and eventually lead to loss of biodiversity". Hence there is a need to encourage and support the use of modern beekeeping which use beekeepers suit instead of smoker. The findings from the study concur with the results from the findings by Musimba (2004), which reported that traditional beekeeping leads to bush fire brought by use of smoker in honey harvesting.

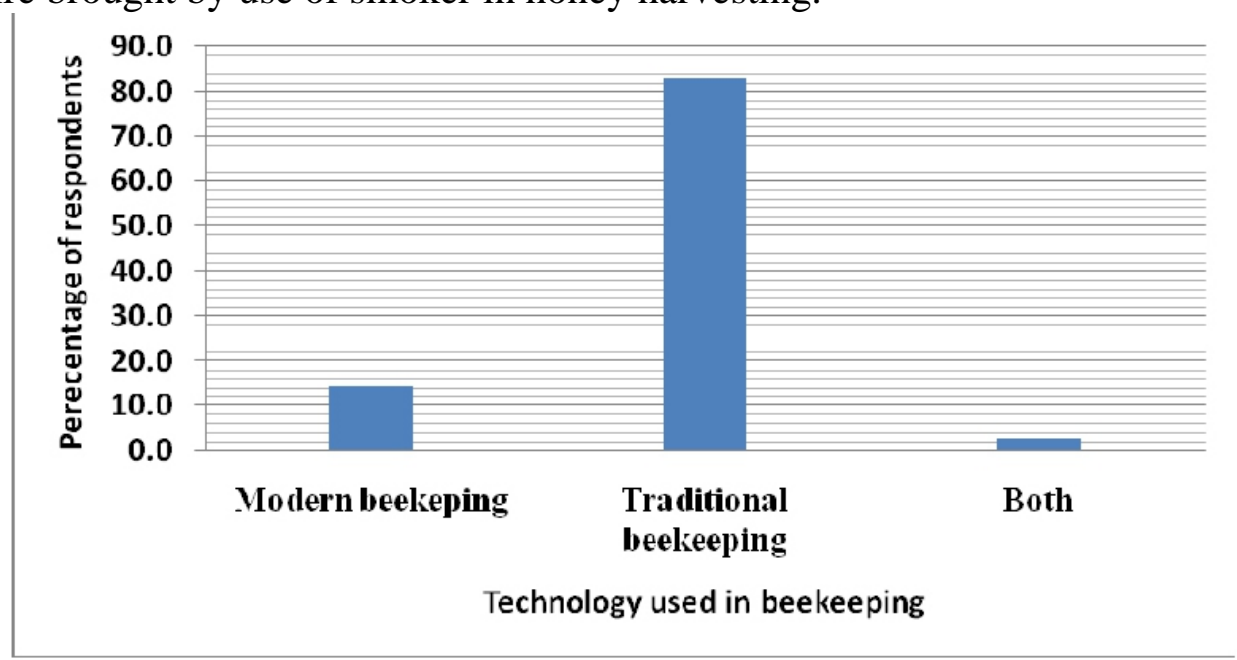

Figure 2: Technology used in beekeeping

Source: field data March, 2016.

The correlations between numbers of beehives and liters of honey produced in a year

Pearson Coefficient is a type of correlation coefficient that represents the relationship between two variables that are measured on the same interval or ratio scale. Values for the Pearson Correlation will be between -1 and 1 . The closer the value is to 1 or -1 , the stronger the linear correlation negative values denote negative linear correlation. When there is a perfect linear relationship every change in the $\mathrm{x}$ variable is accompanied by a corresponding change in the y variable (Gravetter, 2010).

Table 3: correlations between numbers of beehives and litres of honey produced in a year

\begin{tabular}{cccc}
\hline & Pearson Correlation & 1 & $.718^{* *}$ \\
Number of beehives & Sig. (2-tailed) & & .000 \\
Liters of honey produced in & $\mathrm{N}$ & 70 & 70 \\
a year & Pearson Correlation & $.718^{* *}$ & 1 \\
& Sig. (2-tailed) & .000 & 70 \\
\hline
\end{tabular}

Correlation is significant at the 0.01 level (2-tailed)

Source : field data March, 2016. 
Table 3 above indicates the strong relationship of 0.718 between numbers of beehives and liters of honey produced in a year this implies that numbers of beehives correspond to the produced liters of honey in a year since it is between 1 or -1 .

\section{Contributions of Beekeeping on Forest Conservation and Poverty Alleviation in Moshi Rural District}

With regard to contributions of beekeeping on forest conservation and poverty alleviation in Moshi rural district the following contributions were revealed that $91.4 \%$ of the respondents agree that bees pollinate plants where the respondents portrayed pollination in their agricultural fields of coffee, beans and maize. While $8.6 \%$ of the respondents disagreed that bees do not play role in plants pollination this is due to small scale practice of beekeeping also lack of education from extension officers and knowledge on bees major activities.

\section{Contributions of beekeeping to employment opportunities}

Findings reveals that $75.7 \%$ of the participants disagreed that beekeeping does not provide employment opportunities while $24.3 \%$ of the respondents agreed that beekeeping provides employment opportunities. Majority (92.9\%) of beekeepers practice small scale production with beehives ranging between 1 up to 10 hence considers beekeeping as a hobby and extra income generation activity while minority considered beekeeping as part of their activity because of income generation from sell of honey and bees wax. Most of the beekeepers opposed to the fact that beekeeping contributes to employment opportunities because it does not consume plenty of time and most of their time, beekeepers perform other economic activities while beekeeping is termed as a hobby and activity inherited from the fore fathers purposely for food and medicine.

However finding from URT (1998), reported that honey bees facilitate self employment and income generation to individual by sell of honey products, the generated income from beekeeping activities may be used to pay social services like education, electricity, health, transport and build better housing which facilitates poverty alleviation. Furthermore findings by UNDP (2002), reports that, beekeeping is a potential source of additional income; it is seen as an important occupation and part of rural life worldwide where access to income is limited.

\section{Contributions of beekeeping in poverty alleviation}

Data from table 3 shows contributions of beekeeping in poverty alleviation reveals that $60 \%$ of the respondents reported that beekeeping contributed to source of livelihood while $31.4 \%$ of participants revealed that 
beekeeping contributed to income generation and finally $8.6 \%$ of respondents reported that beekeeping neither contributed to livelihood nor income generation.

Majority of beekeepers disagreed to the fact that beekeeping contributes to poverty alleviation and this is because they practice small scale and their focus is not on sale but domestic uses such as medicine and food. Upon wealth ranking among respondents it was revealed that most of the beekeepers had properties like lands and houses but they obtained them from their other predominant activities.

Table 4: Contributions of beekeeping in poverty alleviation

\begin{tabular}{cc}
\hline Poverty alleviation & Percent (\%) \\
\hline Income generation & 31.4 \\
Source of livelihoods & 60.0 \\
None of the above & 8.6 \\
\hline Total & 100.0 \\
\hline
\end{tabular}

Source: field data March, 2016.

\section{The contributions of beekeeping in forest conservation}

Beekeeping contributes to forest conservation through the process of pollination also preserves water sources from practice of beekeeping along water boundaries. Data obtained from the field revealed that $40 \%$ of sampled beekeepers agreed that beekeeping contributed to forest conservation through afforestation program via pollination, $31.4 \%$ of the respondents said contribute to pollination $18.6 \%$ of the respondents increase of crop harvest, $5.7 \%$ of the participants improve vegetation and $4.3 \%$ of the respondents were neither afforestation, pollination, improve vegetation nor increase crop harvest.

The findings concur with Crane (1999), who reported that, bee pollinators strongly influence ecological relationships, ecosystem conservation and stability, genetic variation in the plant community, floral diversity, specialization and evolution.

Generally bees play an important role in ecosystem services and there is a need to strengthen the beekeeping assets which are natural assets: bees, a place to keep them, water, sunshine, biodiversity and environmental resources. Human assets: skills, knowledge, good health and strength, and marketing expertise and the physical assets: tools, equipment, transport, roads, clean water, energy and buildings. Also social assets: help from families, friends and networks, membership of groups and access to wider society, market information and research findings. Lastly financial assets: cash, savings and access to credit or grants (Verner, 2010). 
Table 5: The contributions of beekeeping in forest conservation

\begin{tabular}{cc}
\hline Contributions & Percent (\%) \\
\hline Pollination & 31.4 \\
Increase crop harvest & 18.6 \\
Improve vegetation & 5.7 \\
Afforestation & 40.0 \\
None of the above & 4.3 \\
\hline Total & 100.0 \\
\hline
\end{tabular}

Source: field data March, 2016.

\section{Conclusion}

The general objective of this study was to examine the role of beekeeping on forest conservation and poverty alleviation in Moshi rural district. The study found out that financial constraints and lack of supporting services to beekeepers were the most cited challenges of beekeeping in honey production and market in Mweka and Kibosho Umbwe villages. Majority (25.7\%) of beekeepers lacks access to permits on Kilimanjaro half mile forest reserve for conducting their beekeeping activity particular in Mweka village.The technology used in beekeeping mostly (82.9\% respondents) as depicted in figure 2 is the traditional beekeeping with the use of smoker in harvesting of honey which is dominated by local market in both Mweka and Kibosho Umbwe villages.

The contribution of beekeeping in employment opportunities was disagreed by most (75.7\%) of the respondents in Moshi rural district as they regarded it an ancestry inherited and domestic activity. Majority of respondents agreed to facts that beekeeping contribute to forest conservation through plants pollination and acts as source of livelihood.

\section{Recommendations}

The central government should provide beekeepers officers in the ward and village offices of Mweka and Kibosho Umbwe so that the beekeepers can easily access knowledge on how to conduct the beekeeping activities. Also supporting services, markets and market information should be considerably provided by the government to the beekeepers.

Education and trainings on beekeeping activity should be provided to the beekeepers and community at large through village and community meetings, seminars and workshops both in Mweka and Kibosho Umbwe villages. The forest policy makers should include beekeeping as among forest projects which enhance conservation through pollination of bees. They should also consider using participatory method in forest conservation by using the local community particular the beekeepers in Mweka village.

Since beekeeping potential has not yet successful being explored in Mweka and Kibosho Umbwe villages towards effective forest conservation 
and poverty alleviation supporting services should be strengthened in beekeeping activity from private dealers, NGOs, CBOs and government

\section{References:}

Bradbear, N. (2003). Beekeeping and sustainable liveliood. Agriculture supply system division. Rome: Food and Agricultural Organization.

Bradbear, N. (2009). Bees and their Role in Forest Livelihood. Rome: Food and Agricultural Organization.

Crane, E. (1999). World history of beekeeping and honey hunting. Newyork: Taylor \& Francis.

Gravetter, F. (2010). Essentials of statistics for the behavioral science. New york: Cengage learning.

Hilmi, M. (2012). Beekeeping and sustainable livelihood. Rome: Food and Agricultural Organization.

Keyyu. (2003). Proceedings of the Fourth Annual Scientific Conference. Arusha: Tanzania Wildlife Research Institute.

Krell.R, (1996). Value Added Production from Beekeeping. Rome: Food and Agricultural Organization.

Mkamba, G. (2013). An Overview of Forest and Beekeeping Sub-sector : Achievements, Challenges and Priorities for Finacnial year. Tanzania: Ministry of Natural Resources and Tourism.

Mmasa, J. (2007). Economic Analyis of Honey Production and Marketing in Hai District.

Musimba, N. K. (2004). Dryland husbandry for sustainable development in the southern rangelands of Kenya. Kenya: Organization for social science research in eastern and southern Africa ( OSSREA) .

Mwakatobe.A.R. (2001). The Status of Honey Trade - Domestic and International Markets. Arusha: Tanzania Wildlife Research Institute.

Rakesh, G. (2014). Beekeeping for Poverty alleviation and Livelihood Security. Netherland: Springer.

Salim, E., \& Ullsten, O. (1999). Our Forest, Our Future. England: Cambrige University Press.

UNDP. (2002). Poverty and conservation. Kenya: Honey care Africa limited.

URT. (1998). National Beekeeping Policy. Tanzania: United Republic of Tanzania.

URT. (2001). Marketing Study on Honey and Beeswax . Tanzania: Ministry of Natural Resources and Tourism.

USDA. (2012). The USA Beekeeping Industry. USA: United States Department of Agriculture.

Verner, D. (2010). Reducing poverty, protecting livelihoods and building asets in a changing climate. USA: World bank publications. 